\title{
The Painting Technical Characteristics and Sources of Hungarian Painter MihÁLy MunkÁCsy in the 19th Century
}

\author{
Xiaojie Zhang \\ National Academy of Chinese Theatre Arts \\ Beijing, China
}

\begin{abstract}
Munkácsy was hailed as the greatest painter in Hungarian history for his critical realism painting style. As early as the 1950s, his works have been in China, so many Chinese are familiar with and love his works. The author studied the painting technical characteristics and sources of the Hungarian painter Mihály Munkácsy.
\end{abstract}

Keywords-Munkácsy; realism; technique

\section{INTRODUCTION}

The Hungarian National Gallery in Budapest has the world's richest collection of Munkácsy's works, and Munkácsy ${ }^{1}$ was hailed as the greatest painter in Hungarian history for his critical realism painting style. His works are considered to be the highest status of the national level of painting, and he is one of the few painters who reached the peak of painting techniques in Austro- Hungarian region in the 19th century. Many of his works are taken from the labor's life from bottom of the society and received the attention of critics. His art was real and plain, full of moral power, he could be regarded as the most prominent and determined realist painter in Europe.

\section{STUDYING THE TECHNICAL CHARACTERISTICS AND} SOURCES OF MIHÁLY MUNKÁCSY'S PAINTINGS FROM THE

\section{RESEARCH ON MUNKÁCSY’S ARTISTIC EXPERIENCE}

The author visited and studied the works of Munkácsy in the Hungarian National Museum, and purposefully collected and sorted out his life and learning experience, and photographed the works involved. The National Museum has collected more than 30 major realist style works of Munkácsy. The author summarized them according to time and found that Munkácsy's painting techniques has a clear demarcation between 1865 and 1866, before that time his works are delicate, colorful, and genre-based; but after that time his technique is clearly has French romantic style and a realistic style that is gradually subtle and deep. The texture, strokes, and texture of the paintings all have obvious features.

painter
Mihály Munkácsy (February 20, 1844 - May 1, 1900) Hungarian

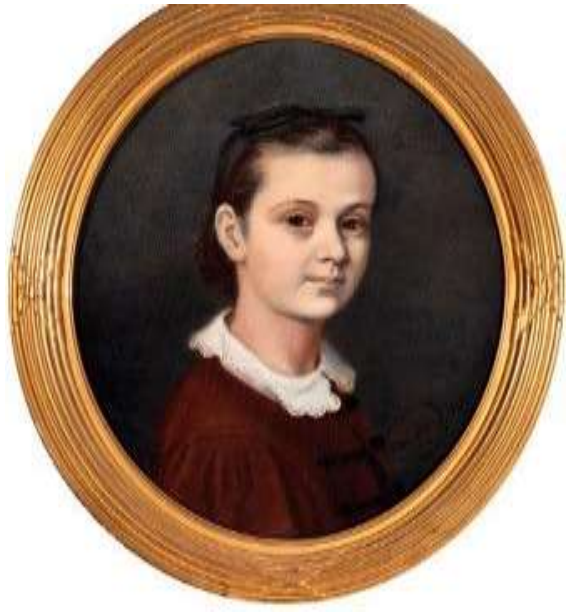

Fig. 1. Munkácsy’s early work.

Munkácsy was born in Monkach in the AustroHungarian Empire period. Later his parents died so he lived with his uncle's life. He once lived as a carpenter, and his poor life experience when he was young made him has a profound experience for the lives of the poor people, which laid the foundation for his future creation. Munkácsy's art experience began with learning from painter Elek Szamossy. From 1855 to 1859, Elek Szamossy worked in Venice and later moved to Bekeschow in Hungary where Munkácsy's uncle lives to paint portraits. In this town, he discovered the talent of Munkácsy, so he passionately taught young Munkácsy and took him to study portraits in southern Hungary. In 1863, they went to Pest, Hungary's largest city (now is part of Budapest), where he consulted with famous artists of the time, after which Antal Ligeti, the director of the Hungarian National Gallery's painting gallery, gave the young artist an opportunity to copy works, he learned from the works of masters.

Munkácsy, with the help of Antarig, was awarded a grant to study abroad. In 1865, he studied with Professor Karlal at the Vienna Academy of Fine Arts and later he was forced to leave the academy after half a year because he was unable to C3\%A1csy 
pay the high tuition fee. At the same time he studied the museums and galleries in Vienna and was impressed by the art of Rubens and Rembrandt.

In his early career period, Munkácsy mostly described the scene of the daily life of farmers and the poor. For example: "Easter Celebrations" (1865). In 1866 he studied at the Academy of Fine Arts in Munich. In 1868 he went to the Düsseldorf Academy of Arts to study popular genre painting with the painter Ludwig Knaus. The Düsseldorf Academy of Art is a well-known public art academy located in Düsseldorf, the capital of North Rhine-Westphalia. In the history of art, it showed great influence and artistic individuality. The Düsseldorf Art School became a rising international art school in the 19th century.

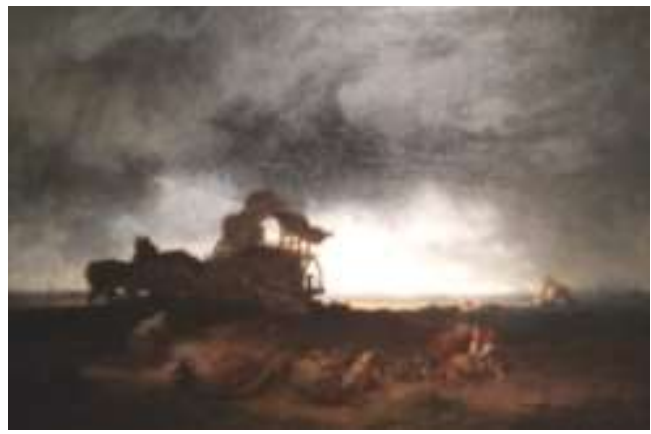

Fig. 2. Puszta Storm.

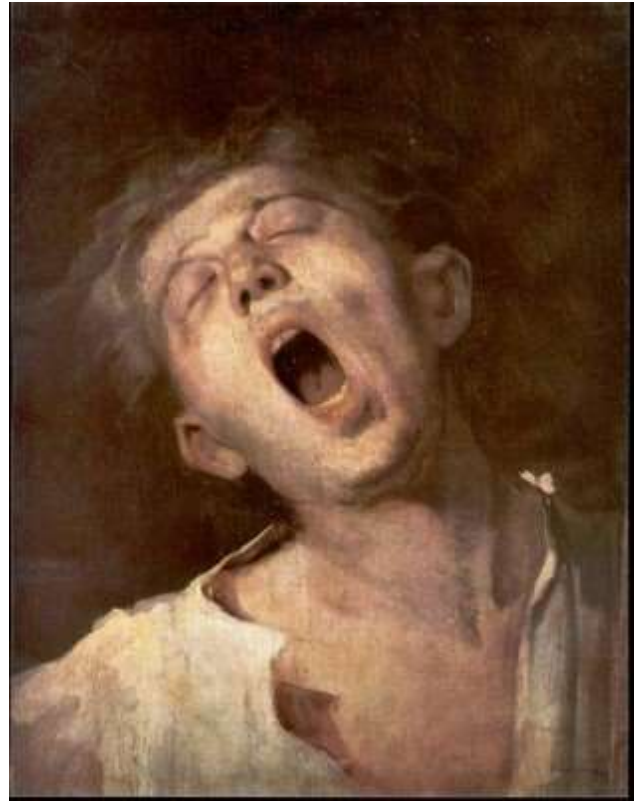

Fig. 3. Yawning Apprentice.

In the next few years, he was more concerned with the performance of portrait painting (Puszta Storm, 1867) "Figure 1". From Düsseldorf's genre painters, he learned to show different emotions in his characters. In 1867, he went to Paris to visit the World Expo. After his trip to Paris, his art style became more relaxed, his picture is wider and his tones are more abundant, which is closely related to his influence on modern French painting. Mihály Munkácsy learned from the works of realist painters Courbet, Miller and Corot. "Yawning Apprentice" can be seen as the first step toward a new transformation. He was a leader full of humor and idealism, understanding and experiencing suffering is the most valuable element in Munkácsy's realist art "Figure 2". He created a large number of large-scale oil paintings with unique personalities. In 1869, Munkácsy's highly praised work "The Last Day of the Condemned" was considered as his first masterpiece "Fig. 3". This work won a gold medal at the Paris Salon in 1870 and Munkácsy became a popular painter. This work shows the oppressive, moral uncertainty that visually creates the psychological torture caused by the upcoming tragic ending. However, it precisely reflects the capability of this Hungarian master painter. ${ }^{3}$

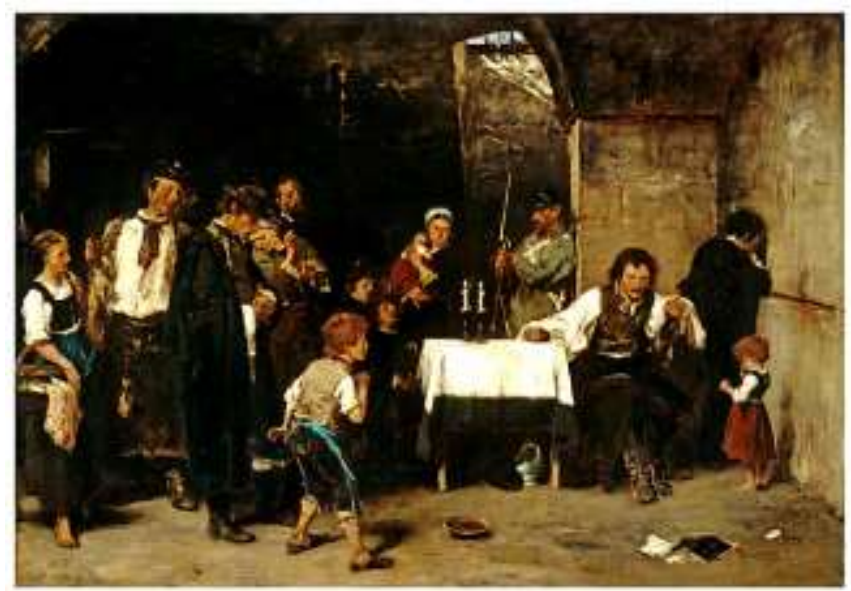

Fig. 4. The Last Day of the Condemned.

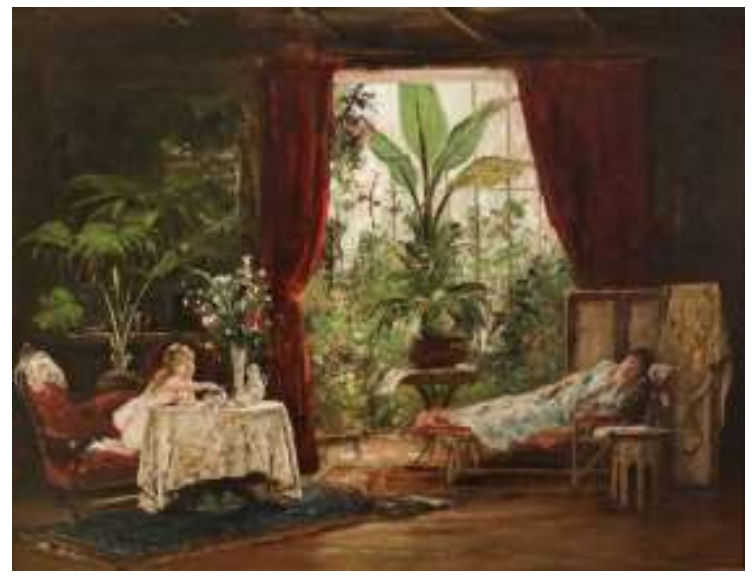

Fig. 5. Salon painting-Small thief of sugar.

Munkácsy's career peak was from 1873 to 1875 when he created The "Midnight Rambler", "Farewell", "The Woman Stirs Milk", and "The Pawnshop". These works continue to maintain his country-style paintings with a gloomy tone of realism. At night he painted a variety of homeless people for creation. In 1873 Munkácsy visited Laszlo Pals, a friend of Barbizon, and was invited to stay there. Barbizon is the art

1958 
world of Jean-François Millet, Camille Corot, and Gustave Courbet. Artists here made a perfect combination of nature and art, making the painting full of poetic.

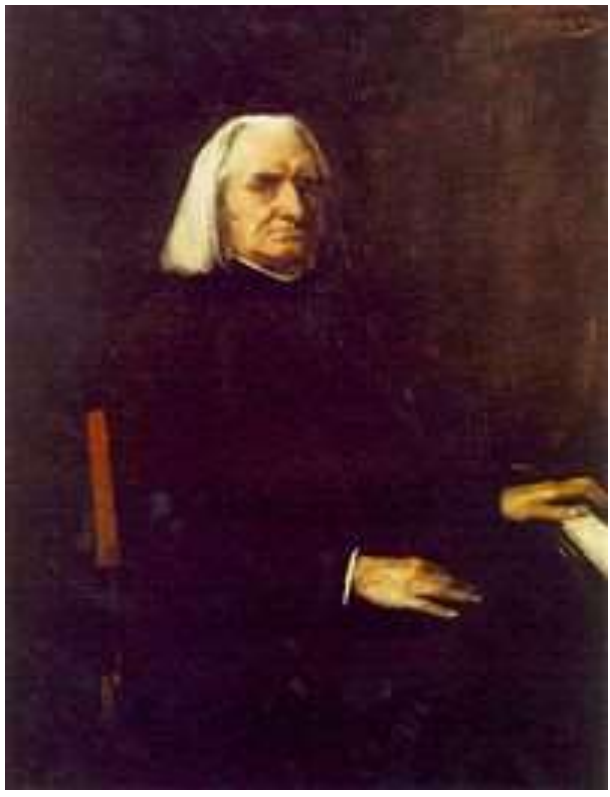

Fig. 6. Portrait of Lester.

Munkácsy married in 1874, and his wife was Cesar Papel, the widow of De Maras. After that, his style has changed from typical realism to create sweet salon paintings and still life paintings. In the late 1970s, he worked with Palá in Barbizon and painted colorful landscapes such as "Dust Road", "Corn field", and "Walking in the Woods". In 1878, Munkácsy created a portrait of Lester. This portrait is a halflength portrait by 42-year-old Munkácsy for the 75-year-old Lester. Lester died on July 31, 1886, so this work is also the last oil painting portrait of Lester. In order to present the truest appearance of the "king of the piano" in his later years, Munkácsy advocated realism removed all the decorative effects from the painting and focused on highlighting Lester's character and temperament, especially the cheek under the light and the slender hands that create magic. In 1882, Munkácsy who was nearly 40 years old, and already made a name for himself. In order to pay tribute to him, Lester specially wrote a work for him in his 71 years age, "Hungarian Rhapsody No. 16". The main theme of Lester's music cites a Hungarian folk song, which is also Munkácsy's favorite melody, premiered at a festival in Budapest.

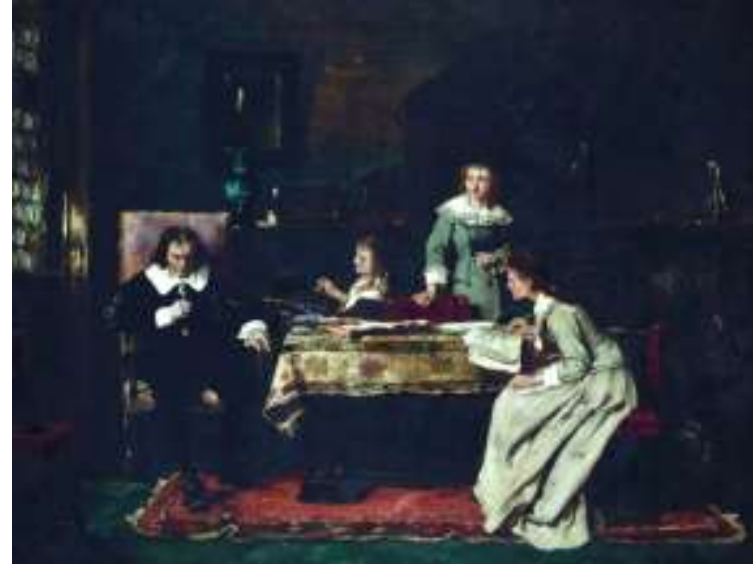

Fig. 7. Milton listens to her daughter dictates Paradise Lost

Afterwards Munkácsy painted a historical type of work, "Milton listens to her daughter dictates Paradise Lost", which marks a new milestone in his work. This work was purchased and successfully sold by the Austrian art dealer Charles Sedelmeyer, who provided Munkácsy with a tenyear contract. The deal made Munkácsy rich and became a veteran member of the Paris art world.

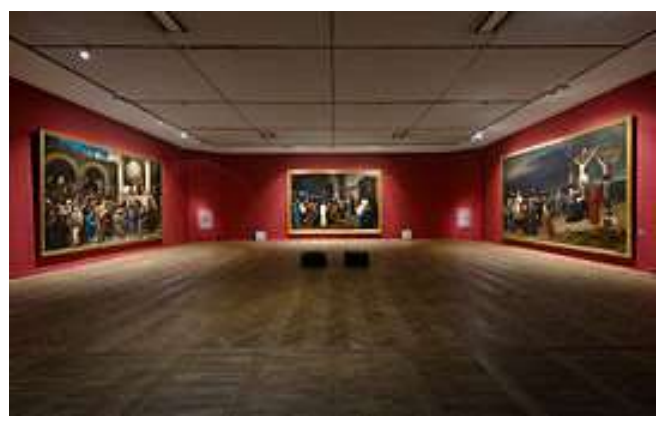

Fig. 8. Munkácsy's The Trilogy of Christ in the Delhi Museum.

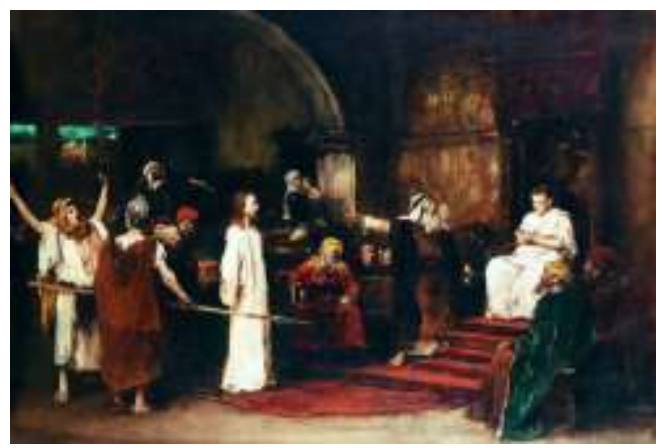

Fig. 9. One of the trilogy of Christ - Pilate in front of Christ

Sedelmeyer hopes Munkácsy to draw a representative large-scale creation. They decided to choose a theme from the Bible. In 1882, Munkácsy painted "Pilate in front of Christ", followed by 1884, and in 1896 he finally completed The Trilogy of Christ. Sedelmeyer toured Europe and the United States with these three giant oil paintings. They were purchased by US department store giant John Wanamaker, and were exhibited in Philadelphia on every Easter Holiday. 
At the 1988 auction, Joey and Toby Tanenbaum purchased the "Pilate in front of Christ" from the Trilogy of Christ and donated it to the Art Museum of Hamilton in 2002. The Museum of Art in Hamilton leased it to the Delhi Museum in Debreceni since 2002. Two of the other works were owned by the Hungarian national and American art collector Imre Pkhkh. After returning to Canada, "Pilate in front of Christ" was directly purchased by the government of Hungary with $\$ 5.7$ million in February 2014. Now these three works are placed in a special hall at the Delhi Museum. The author specially visited the Delhi Museum in Debreceni to study the "Trilogy of Christ", and analyzed the characteristics of his painting techniques. ${ }^{4}$

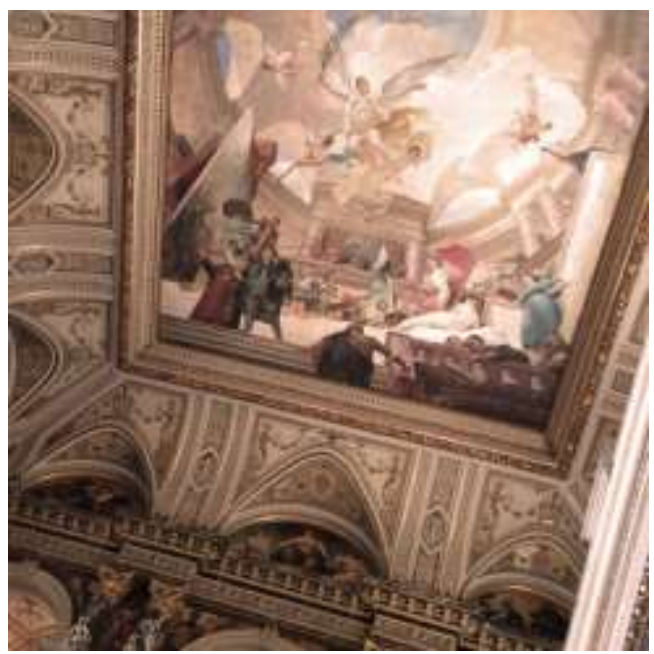

Fig. 10. Zenith painting of the Kunsthistorisches Museum.

At the end of Munkácsy's career, he completed two monumental works: The Conquest in the Hungarian Parliament Building and the large zenith painting he was commissioned to draw at the Kunsthistorisches Museum. The project was completed in 1888 and was called "The Glory of the Renaissance". Despite the secular success and social prestige that made Munkácsy a celebrity, but he was always uncertain and always questioned his talents. By the 1890 s, his depression had developed into a serious mental illness.

At the end of his life, the disease expended more and more of his energy, and finally the darkness arrived, he completed two works, one of which was Strike (1896), he expressed his passion in a new style to present different styles of the times. In the summer of 1896, Munkácsy's health declined sharply. After treatment in Baden, he returned to Paris. Later he was taken to the mental hospital in Endenich near Bonn. On May 9, 1900, Munkácsy died there and was buried in the Kerepesi Cemetery in Budapest. The author specifically worshiped the great Hungarian painter in the cemetery. When Munkácsy was young, he worked as a carpenter in Bekeschow, but eventually he became a painter who conquered the whole world with canvas. In addition to his artistic knowledge and talent, he was also known as a

\footnotetext{
4 "Munkácsy's The Trilogy of Christ”,Kurti Katalin, Mind Press,
} Budapest, 1989. sensitive "sociologist". He showed urban and rural life in European and Hungarian's social life. His pictures depict his contemporary social history and events. He has deeply studied and portrayed the characteristics of that era, his realist themes and "The Trilogy of Christ" made him acclaimed throughout the world.

In 2005, the National Art Museum of Hungary hosted the first comprehensive painting exhibition of Munkácsy in Budapest. His works are scattered around the world and up to 120 pieces are borrowed from different institutions, museums and private collections. A book entitled "The World of Munkácsy" was published at that time. The threemonth exhibition was a rare feast for Hungarians. Some of Munkácsy's paintings were collected at the Milwaukee Art Museum; Dayton Institute of Art (Ohio) and Albany (New York) Museum of Art and History; as well as Frye Art Museum in Seattle Washington which first collect his works; his paintings were also exhibited and displayed by the Arad Museum of Art (Romania) and the Ferenc-Mola Museum of Art (Szeged, Hungary). ${ }^{6}$

\section{UNDERSTANDING THE DEVELOPMENT OF HUNGARIAN FINE ARTS BASED ON THE EXCHANGES BETWEEN THE ACADEMY OF FINE ARTS AND CONTEMPORARY PAINTERS AND GAINING A DEEPER COMPREHENSION OF MUNKÁCSY.}

During the time in Budapest Hungary, the author exchanged ideas with Mr. Kosha Janash, Director of Oil Painting Department of the National Academy of Fine Arts. The Hungarian Academy of Fine Arts was established in 1905, which means the original painting system of Hungary was built from the beginning of the 20th century, but its inheritance and accumulation are profound. Based on historical reasons, the strength of the Austro-Hungarian Empire and the House of Habsburg dynasty ruled for more than two hundred years have laid a foundation for the Hungarian painting system.

Mr. Kossa Janash is a contemporary follower of Munkácsy's art. His works often use certain images in Munkácsy's works to reorganize the picture and use lines and graphics to organize characters and pictures to express his ideas, which is full of contemporariness. He elaborated his view of Munkácsy's art concept and proposed that Munkácsy's technique has certain defects in the material use. Because Munkácsy's early creative life was under economic pressure, he used asphalt as a painting material. As a result, his works were constantly darkened and absorbed by the bottom layer. Now, many of the unfinished works may actually is this technical problem has been alleviated by modern technology. Munkácsy's large-scale works can better reflect his painting style and technical characteristics. His background color is mostly deep, he was very fond of white robes and headscarves. These whites are summarized by him as a relatively overall color block, the pleats for the division

\footnotetext{
5 “Munkácsy”, Zoltan Fakkas, Hungarian National Museum, 1941.

Munkácsy Museum Foundation website:

http://munkacsyalapitvany.hu/hu/munkacsy-mihaly?start=5
} 
of the white area is weakened, the face of the character is overall, the strokes are generalized, free and easy.

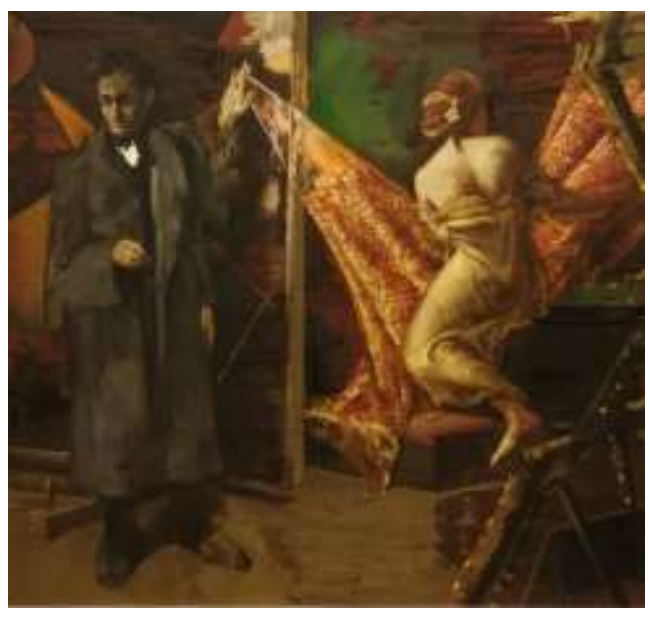

Fig. 11. Kossa Janash's work.

\section{STUdying THE CHARACTERISTICS OF MUNKÁCSY'S TECHNIQUES FROM HUNGARY'S NATIONAL CULTURAL THEME}

Hungary is an agricultural animal husbandry country. According to legend, it is inextricably linked with the Huns. Historically, they came from the Don River basin in Russia, so more or less they retained the customs of the prairies. After the historical changes and integration, most of the people here believe in Catholicism. In their domestic religious festivals, many activities with ethnic traditions are held, such as Christmas and Easter. Hungary has a very precious history of national art. The richly decorated national traditional costumes and supplies show a strong national art color. Hungarian art was born on the vast Great Plains, the peasants lived there are the founders of these art works. Their ethnic costumes have its characteristics. In the northeastern Gomer region and in the west city Olseg still use ancient techniques which burning pottery with clay. These are the typical folk arts of Hungary.

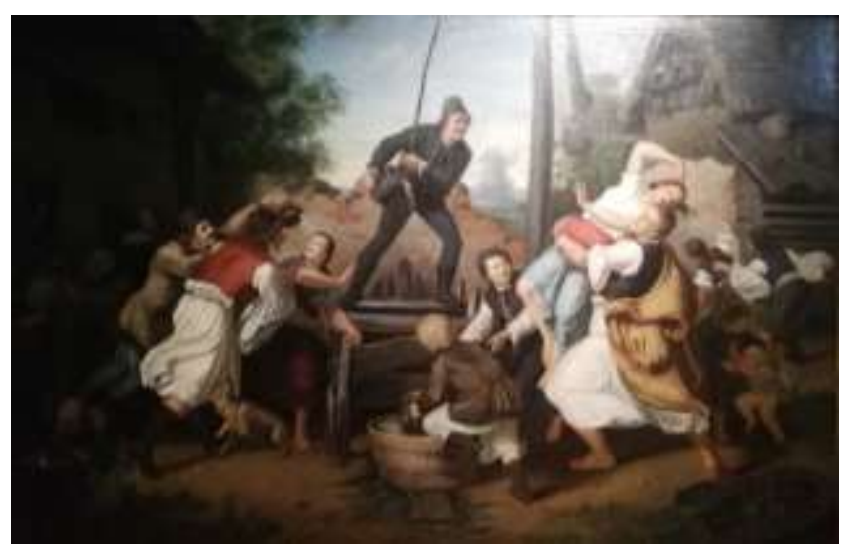

Fig. 12. Easter celebration.

Holloko where more than 100 kilometers from Budapest, is a village in the World Cultural Heritage List. In traditional festivals people dressed in national costumes and held celebrations. The author interviewed some Hungarians who had some folk customs. For example, during the Easter water splashing activity, the boy grabbed the girl and wet her body with water; the boy gently stroked the girl with wicker whip, and the girl took the small basket with cakes and candy to share with the boy; there was also parade, dance and other activities. Munkácsy's early creation "Easter Celebration" (1865) was based on this. This is an interesting customs in Hungary, there is an Easter activity are very similar to the Songkran Festival of Chinese Dai people. Men use buckets to pour water on unmarried girls, the more water they are poured, the more popular they are. The characters in the work are all dressed in traditional white clothes, Hungarian traditional folk costumes are decorated with white shirts, dresses with black red and green colors, which embodies the enthusiasm and unrestrained ethnic characteristics. The white and dark colors of Munkácsy's works have great contrast which is an important feature of his works.

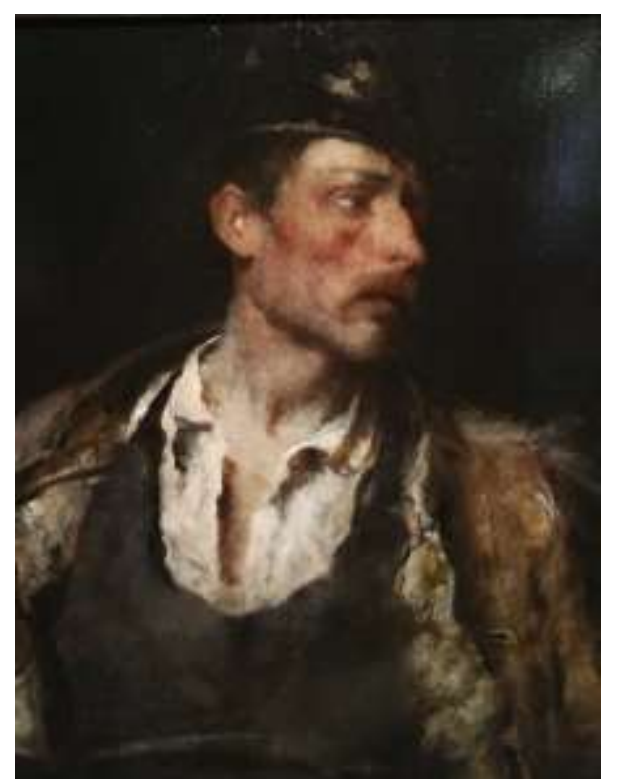

Fig. 13. The man with a pipe (partial).

The author copied Munkácsy's work "The Man with a Pipe", through copying the author found that his use of white color is very clever, the clothing pattern is simple and holistic, the early brush strokes are thicker, and later by rubbing and using thin oil to reconcile the color so that the brush strokes hang on the surface of the underlying scale to create a glass film effect.

\section{The Status QuO OF HUNGarian ART CUlture}

There is a street of gallery and antique shops in Budapest Hungary, which is the core commercial area of Budapest. Among them, the Virag Judit Art Museum is a larger art gallery of Budapest Art Street. For many years, it has organized exhibitions and sold the Hungarian master-level art works. Most of the works shown there are paintings from the 19th to the middle of the 20th century. Including the works of Munkácsy, we can see that the continuation of the 
paintings in Hungary after Munkácsy era which can be used as a useful supplement to the collections in museums.

During the Budapest period, the author participated in the Budapest Winter Art Auction, where annual spring and winter art auctions are held. The auction works here are all art works from 50 years to 100 years. Most of them are works of Hungarian local artists, including two sketchy manuscripts of Munkácsy. In addition, there are many works of well-known modernist artists, but it can be seen that these works have been in circulation for several decades in the market, so they already have relatively stable artistic value, there will be no phenomenon of overheating or overvalue.

\section{CONCLUSION}

Munkácsy is a romantic painter and also a realist painter. The theme of painful performance is one of the most valuable elements of Munkácsy's realist art; and one of the sources of his romanticism is the national consciousness born in civil society. Without the contribution of Munkácsy, the 19th century Hungarian painting art was not complete. His works were considered to be the highest status of the national level of painting. He was one of the few painters who reached the peak of painting techniques in Austria and Hungary in the 19th century. Many of his work themes were taken from people's life from the bottom of the society and received the attention of critics. His art was real and plain, full of moral power, he could be regarded as the most prominent and determined realist painter in Europe.

\section{REFERENCES}

[1] Wikipediahttps://en.wikipedia.org/wiki/Mih\%C3\%A1ly_Munk\%C3 \%Alcsy.

[2] Végvári, "The Life and Works of Munkácsy”, Academic Press, 1958.

[3] Kurti Katalin, "Munkácsy's The Trilogy of Christ", Mind Press, Budapest, 1989.

[4] Zoltan Fakkas, "Munkácsy", Hungarian National Museum, 1941.

[5] Munkácsy Museum Foundation website: http://munkacsyalapitvany.hu/hu/munkacsy-mihaly?start=5. 